Agro-Science Journal of Tropical Agriculture, Food, Environment and Extension Volume 9 Number 2 Mav 2010 PP. .111- 124

ISSN 1119-7455

\title{
EFFECT OF SWARD TYPE, CUTTING FREQUENCY AND FERTILIZER-N APPLICATION ON PASTURE ESTABLISHMENT, GROWTH AND YIELD IN GUINEA GRASS-VERANO STYLO PASTURES.
}

\author{
Onyeonagu, C. C. ${ }^{*}$ and Asiegbu, J. E. \\ Department of Crop Science University of Nigerian, Nsukka. \\ "Corresponding Author, e-mail: onyeonagu@yahoo.com
}

\begin{abstract}
This experiment was a $3 \times 3 \times 2$ factorial laid out in a randomized complete block design and was replicated three times. Treatments comprised three sward types (pure grass, pure legume and grass/legume mixed swards), three cutting regimes (4 weeks, 8 weeks and 12 weeks) and two nitrogen fertilizer rates $\left(0\right.$ and $\left.300 \mathrm{~kg} \mathrm{~N} \mathrm{ha}{ }^{-1}\right)$. Increasing the interval between harvests increased the number of branches per plant, number of leaves per legume plant, and heights of grass and legume species. The application of $N$ increased heights of grass and legume plants, with no effect on the number of leaves per plant and number of branches per legume plant. Fertilizer effects on height of grass and legume plants were generally, not significant during the later periods of 2006 and 2007. There were significant reductions in the height, number of nodules per plant, length of longest root per plant, number of branches per plant, number of leaves per plant, and dry matter yields of leaf, stem and root fractions per verano stylo plant in the grass-legume mixed swards when compared with the pure legume swards.
\end{abstract}

Key words: Interval between cuts, nitrogen, grass-legume mixture

\section{INTRODUCTION}

A lot of experimental work has been conducted on the response of tropical sown pastures to cutting management and nitrogen fertilization (Haggar, 1971; Humphreys, 1980; Bamikole et al., 2004). However, little is known on how verano stylo (Stylosanthes hamata) grown with or without guinea grass (Panicum maximum) in the derived savanna will respond to different $\mathrm{N}$-fertilizer application rates and different cutting regimes.

Cutting management is critical to stand longevity (Guay, 2001). Grass stands are weakened if cutting intervals are too frequent, leading to a decline in the stand because of insufficient energy reserves for regrowth (Jung et al., 1994). Infrequent cutting can also weaken the stand through reduced seedling and tiller survival, due to excessive shading from the forage canopy (Jung et al., 1994). The value of the addition of legumes to a stand of grass is well known (Guay, 2001; Casler and Walgenbach, 1990). Maintenance of legume in pastures is imperative in terms of sustainability of mixed species swards (Turner et al., 1998). Nitrogen fertilization has been found to reduce the legume content in mixture with grass (Guay, 2001). therefore, the influence of nitrogen application on the legume component needs to be investigated. Variations in growth habit, regrowth, and physiological growth requirements make management of grass/legume mixtures difficult (Casler, 1988). It is generally accepted that grasses normally have a competitive advantage over legumes (Wong and Wilson, 2005); however, pasture management techniques such as fertilization and cutting management, are utilized in order to secure a desirable balance (Rhodes and Stern, 1978). This study was designed to evaluate the effect of sward type, cutting frequency and nitrogen application on the establishment, growth and yield in guinea grass and verano stylo pastures.

\section{MATERIALS AND METHODS}

The experiment was carried out in the Department of Crop Science Research and Teaching Farm, University of Nigeria, Nsukka. Nsukka is located at latitude $06^{\circ} 52^{\prime} \mathrm{N}$ and longitude $07^{0} 24^{\prime} \mathrm{E}$, and on altitude of $447.2 \mathrm{~m}$ above sea level. The experiment was a $3 \times 3 \times 2$ factorial laid out in a randomized complete block design and was replicated three times. Treatments comprised three sward types (pure grass, pure legume and grass/legume mixed swards), three cutting regimes (4weeks, 8 weeks and 12 weeks) and two nitrogen fertilizer rates (0 and $300 \mathrm{~kg} \mathrm{~N} / \mathrm{ha}$ ). These gave eighteen treatment combinations. In May 2006, an area of land 37.8 meters long by $13 \mathrm{~m}$ meters wide with an area of $491.4 \mathrm{~m}^{2}$ was ploughed and marked out into three blocks of $37.8 \times 3$ meters each. 
Each block was further divided into 18 plots of 3 $\mathrm{x} 2.1$ meters each with a sampling area of $0.9 \mathrm{x}$ 1.8 meters. Each block was separated by one meter path-way. Basal application of $75 \mathrm{~kg} \mathrm{~K} \mathrm{ha}^{-}$ ${ }^{1}$ and $44 \mathrm{~kg} \mathrm{P} \mathrm{ha}^{-1}$ as muriate of potash and single superphosphate, respectively, was made by broadcasting. Rooted cuttings of Panicum maximum with height of $15 \mathrm{~cm}$ were planted after land preparation at $20 \mathrm{~cm} \times 30 \mathrm{~cm}$ spacing. The seeds of Stylosanthes hamata were planted by broadcast at the rate of $5.6 \mathrm{~kg} \mathrm{ha}^{-1}$. The treatment combinations were allocated completely at random in each of the three blocks. Cutting was done with shears at a uniform height of $7 \mathrm{~cm}$. The effect of type of sward treatment alone on establishment was considered during the first 8 weeks after planting (17 June to 12 August 2006) before the first general cut.

The harvest intervals of 4,8 and 12 weeks gave 4, 2, and 1 samples, respectively, in 2006, and 6, 3 and 2 samples, respectively, in 2007 season. The required quantity of nitrogen as Urea $(46 \% \mathrm{~N})$ was divided according to the number of cuts in a year for each harvest interval and evenly applied on the plot after each cut. The fresh weight of herbage was taken by weighing the fresh herbage harvested within the $0.9 \times 1.8$ meters sample area. The fresh herbage harvested was separated into grass and legume fractions which were weighed separately. A subsample $100 \mathrm{~g}$ each of the grass species and legume per plot were put in paper envelops and dried in a forced air oven set at $80^{\circ} \mathrm{C}$ and weighed after attaining constant dry weight. These were used to calculate the total dry weights of the total herbage and of the different components. Records on plant height, number of branches per plant and number of leaves per plant were taken using the mean of three readings taken at random from the sample area in each plot.

Soil samples were collected at random from twelve representative locations of the field by augering to the depth of $0-20 \mathrm{~cm}$. These were bulked together to form a composite sample from which a sub-sample was taken for soil analysis to determine the physical and chemical characteristics of the site. Meteorological data of rainfall, rain days, ambient temperature, soil temperature, solar radiation, relative humidity, and day length were collected from the Department of Crop Science, University of Nigeria, Nsukka Meteorological Station. All data collected were statistically analysed using the procedure outlined by Steel and Torrie (1980) for factorial experiment in a randomized complete block design. Separation of treatment means for statistical significance was done using the standard error of the difference between two means (s.e.d.). Group t-test was in addition used to compare two sward types during establishment. The 4 and 8 weeks intervals of cut each spanning the yearly harvest period were analysed and compared for effect of season as done by Omaliko (1980). The first, second and third harvest periods, represent the first 8 weeks, second 8 weeks and third 8 week-harvest periods, respectively.

\section{RESULT}

The total annual rainfall was higher at $1613 \mathrm{~mm}$ with 129 rain days in 2006 than at 1570mm with 112 rain days in 2007 (Table 1). The distribution pattern was always bimodal in both years with the heaviest rainfalls in June, August, or October. Rains fell more frequently from July to September. The minimum air temperatures ranged from $17.90-23.33^{\circ} \mathrm{C}$ and $20.03-23.19^{\circ} \mathrm{C}$ for 2006 and 2007 seasons, respectively. The maximum air temperatures were generally highest in the months of November to March or April. The average relative humidity observed was highest during the rainy season in both years from April to October.

The soil of the experimental site (Table 2) was sandy in texture and acidic in reaction. The soil had low amounts of nitrogen content, potassium, magnesium, organic matter, and base saturation at the beginning of the experiment. The soil was low in cation exchange capacity and in available phosphorus.

Plant height, number of leaves per plant, number of nodules per plant, length of the longest root per plant, dry matter yields of leaf, stem and root fractions per verano stylo plant were significantly higher under Verano stylo swards than in the guinea grass/verano stylo mixed swards at 8-weeks after planting (Table 3).

The verano stylo swards produced significantly lower dry matter yield compared with the guinea grass (Panicum maximum) swards or with guinea grass/verano stylo mixed swards at 8 weeks after planting in 2006 (Table 4 ). The guinea grass sward produced higher dry matter yield than Verano sylo sward but had similar effect with the guinea grass/verano stylo mixed swards.

The height of verano stylo plant was higher in plots with pure legume sward compared with where verano stylo was in mixture with guinea grass in 2006 (Table 5). The type of sward had no effect on plant height in 2007. Plant height increased significantly with increase in interval between cuts and with nitrogen fertilizer application in 2006 and 2007.

During the establishment year (2006), verano stylo height was significantly higher at 
Onyeonagu, C. C. ${ }^{*}$ and Asiegbu, J. E.

Table 1: Meteorological Data for Nsukka*

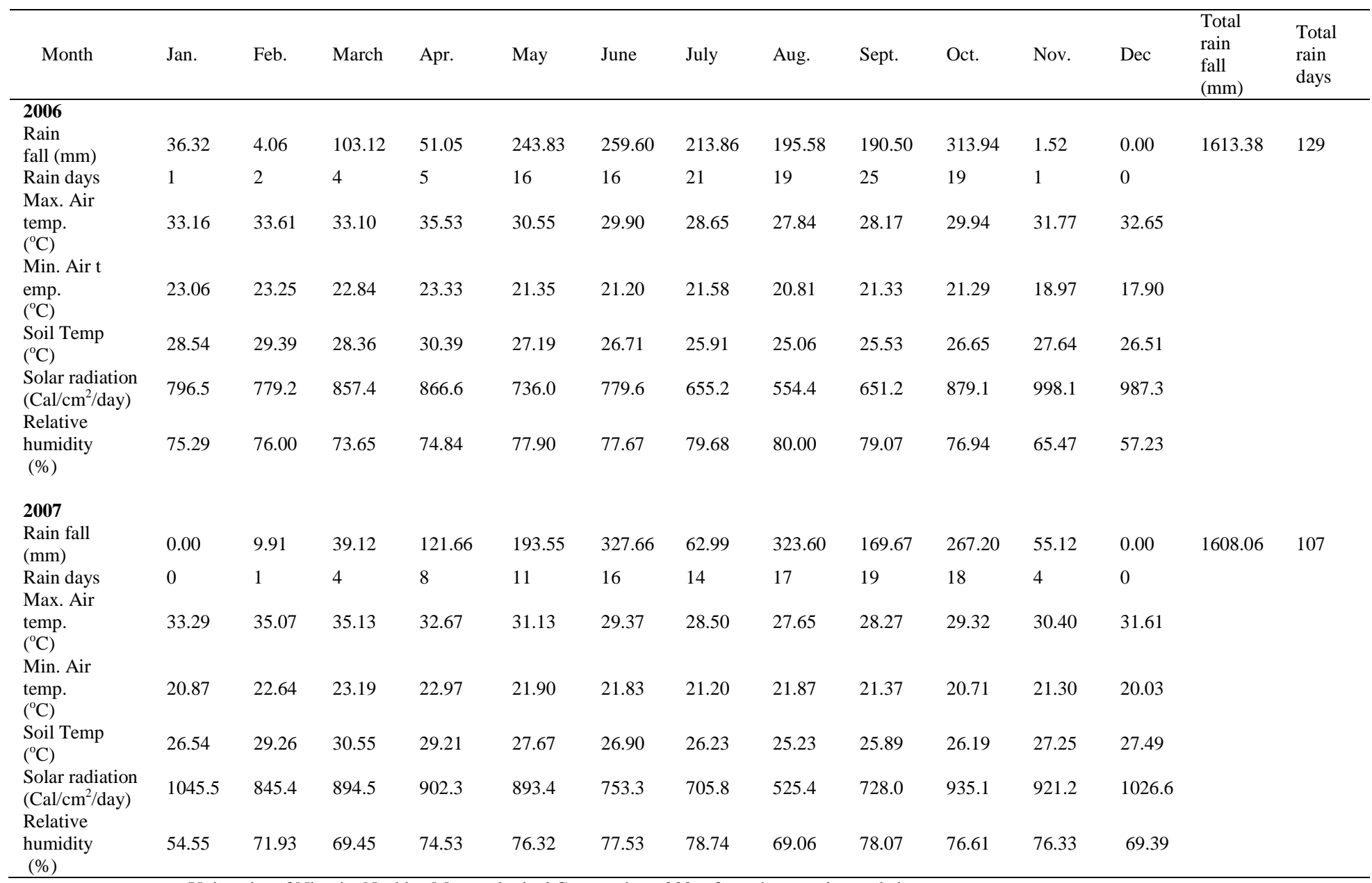

University of Nigeria, Nsukka, Meteorological Centre, about 200m from the experimental site.

Table 2: Soil physical and chemical properties of the experimental site

\begin{tabular}{ll}
\hline Mechanical Properties & \\
\hline Coarse sand (\%) & 40.0 \\
Fine sand (\%) & 54.0 \\
Clay (\%) & 4.0 \\
Silt (\%) & 2.0 \\
Textural Class & Sandy soil \\
Chemical Properties & \\
pH in water & 3.6 \\
pH in KCl & 3.0 \\
Organic carbon (\%) & 0.97 \\
Organic matter (\%) & 1.68 \\
Total nitrogen (\%) & 0.15 \\
Total phosphorus (ppm) & 35.82 \\
Base Saturation & 0.89 \\
Exchangeable Cation (cmol kg-1) & \\
Potassium & 0.27 \\
Magnesium & 2.2 \\
Calcium & 1.8 \\
Sodium & 3.18 \\
Hydrogen & 3.2 \\
Aluminium & 0.8 \\
C.E.C. & 8.4 \\
\hline
\end{tabular}


Table 3: Effect of type of sward on morphological development and dry matter yield (g) of verano stylo (Stylosanthes hamata) at weeks after planting (June 17 August 12, 2006).

\begin{tabular}{|c|c|c|c|c|c|c|c|}
\hline Type of sward & $\begin{array}{l}\text { Plant height } \\
(\mathrm{cm})\end{array}$ & $\begin{array}{l}\text { No. of } \\
\text { leaves } \\
\text { plant }^{-1}\end{array}$ & $\begin{array}{ll}\text { No. } & \text { of } \\
\text { nodules } & \\
\text { plant }^{-1} & \\
\end{array}$ & $\begin{array}{l}\text { Length of } \\
\text { longest root } \\
\text { plant }^{-1}(\mathrm{~cm})\end{array}$ & $\begin{array}{l}\text { Leaf DM } \\
\text { plant }^{-1}(\mathrm{~g})\end{array}$ & $\begin{array}{l}\text { Stem DM } \\
\text { plant }^{-1}(\mathrm{~g})\end{array}$ & $\begin{array}{l}\text { Root DM } \\
\text { plant }^{-1}(\mathrm{~g})\end{array}$ \\
\hline Verano stylo & 20.1 & 35.5 & 112.7 & 14.3 & 0.23 & 0.21 & 0.15 \\
\hline Verano stylo in mixture & 13.2 & 8.1 & 24.9 & 11.2 & 0.04 & 0.04 & 0.03 \\
\hline Variance T-value & 8.43 & 11.29 & 6.85 & 3.96 & 10.23 & 8.54 & 6.83 \\
\hline Pooled d.f. & 34 & 34 & 34 & 34 & 34 & 34 & 33 \\
\hline 2-tail probability & $<0.001$ & $<0.001$ & $<0.001$ & $<0.001$ & $<0.001$ & $<0.001$ & $<0.001$ \\
\hline
\end{tabular}

Table 4: Effect of type of sward on the total herbage yield $\left(\mathrm{kg} \mathrm{ha}^{-1}\right)$ at 8 weeks after planting (June 17 - August 12, 2006).

\begin{tabular}{lc}
\hline Type of sward & Total herbage yield \\
\hline Pure grass & 2760.0 \\
Pure legume & 468.0 \\
Grass-Legume mixture & 2435.2 \\
Mean & 1887.7 \\
s.e.d between 2 sward type means & 189.46 \\
\hline
\end{tabular}

Table 5: Effects of sward type, cutting frequency and fertilizer-N application on height (cm) of verano stylo (Stylosanthes hamata) in 2006 and 2007

\begin{tabular}{|c|c|c|c|c|c|c|}
\hline \multirow[b]{2}{*}{ Sward type } & & & \multicolumn{4}{|c|}{ Cutting frequency (weeks) } \\
\hline & \multicolumn{2}{|c|}{ Fertilizer-N $\left(\mathrm{kg} \mathrm{ha}^{-1}\right)$} & 4 & 8 & 12 & Mean \\
\hline \multirow{3}{*}{ Verano stylo } & \multicolumn{6}{|c|}{2006} \\
\hline & \multicolumn{2}{|l|}{0} & 19.27 & 32.40 & 55.17 & 35.61 \\
\hline & \multicolumn{2}{|l|}{300} & 21.60 & 33.73 & 61.10 & 38.81 \\
\hline & \multicolumn{2}{|l|}{ Mean } & 20.43 & 33.07 & 58.13 & 37.21 \\
\hline \multirow{3}{*}{ Verano stylo in mixture } & \multicolumn{2}{|l|}{0} & 17.77 & 25.67 & 38.60 & 27.34 \\
\hline & \multicolumn{2}{|l|}{300} & 22.47 & 26.03 & 47.03 & 31.84 \\
\hline & \multicolumn{2}{|l|}{ Mean } & 20.12 & 25.85 & 42.82 & 29.59 \\
\hline \multirow{2}{*}{$\begin{array}{l}\text { Cutting Frequency Mean } \\
\text { Fertilizer Mean }\end{array}$} & \multicolumn{2}{|c|}{$0 \mathrm{~kg} \mathrm{Nha}{ }^{-1}=31.48$} & 20.28 & 29.46 & 50.48 & 33.40 \\
\hline & $0 \mathrm{~kg} \mathrm{Nha}{ }^{-1}=31$ & & & \multicolumn{2}{|c|}{$\begin{array}{c}300 \mathrm{~kg} \mathrm{Nha}{ }^{-1}=35.33 \\
2007\end{array}$} & \\
\hline \multirow{3}{*}{ Verano stylo } & \multicolumn{2}{|l|}{0} & 23.1 & 31.5 & 49.5 & 34.7 \\
\hline & \multicolumn{2}{|l|}{300} & 24.2 & 35.4 & 44.6 & 34.7 \\
\hline & \multicolumn{2}{|l|}{ Mean } & 23.6 & 33.4 & 47.1 & 34.7 \\
\hline \multirow{3}{*}{ Verano stylo in mixture } & \multicolumn{2}{|l|}{0} & 22.6 & 34.7 & 48.4 & 35.2 \\
\hline & \multicolumn{2}{|l|}{300} & 24.9 & 36.5 & 48.8 & 36.8 \\
\hline & \multicolumn{2}{|l|}{ Mean } & 23.8 & 35.6 & 48.6 & 36.0 \\
\hline \multirow{3}{*}{$\begin{array}{l}\text { Cutting Frequency Mean } \\
\text { Fertilizer Mean }\end{array}$} & & & 23.7 & 34.5 & 47.8 & 35.3 \\
\hline & \multicolumn{2}{|c|}{$0 \mathrm{~kg} \mathrm{Nha}{ }^{-1}=35.0$} & & \multicolumn{2}{|c|}{$300 \mathrm{~kg} \mathrm{Nha}^{-1}=35.7$} & \\
\hline & & 2006 & & 2007 & & \\
\hline \multirow{4}{*}{\multicolumn{2}{|c|}{$\begin{array}{l}\text { S.e.d. between } 2 \text { Sward Type means }(\mathrm{S})= \\
\text { S.e.d. between } 2 \text { Cutting Frequency means }(\mathrm{C})= \\
\text { S.e.d. between } 2 \text { Nitrogen means }(\mathrm{N})= \\
\text { S.e.d. between } 2 \mathrm{~S} \times \mathrm{C} \text { means }=\end{array}$}} & 1.711 & & 1.69 & & \\
\hline & & 2.096 & & 2.07 & & \\
\hline & & 1.711 & & 1.69 & & \\
\hline & & 2.964 & & 2.93 & & \\
\hline \multicolumn{2}{|c|}{$\begin{array}{l}\text { S.e.d. between } 2 \text { S X C means }= \\
\text { S.e.d. between } 2 \text { S X N means }=\end{array}$} & 2.420 & & 2.39 & & \\
\hline \multicolumn{2}{|c|}{ S.e.d. between $2 \mathrm{C} \mathrm{X} \mathrm{N}$ means $=$} & 2.964 & & 2.93 & & \\
\hline \multicolumn{2}{|c|}{ S.e.d. between $2 \mathrm{~S}$ X C X N means = } & 4.192 & & 4.14 & & \\
\hline
\end{tabular}

the 8-weekly interval between cuts compared with the 4 weeks at the first period of the year (Table 6). Cutting intervals had no effect on verano stylo height during the second period. Fertilizer-N application significantly increased the height of verano stylo at the first period but had no effect on plant height at the second period of the year when compared with where no nitrogen was applied. During the first period of the year, the pure verano stylo swards produced taller plants compared to where verano stylo was grown in mixture with guinea grass. Verano stylo plants appeared to be taller at the early period than at later period.

The height of the legume component was increased with the higher cutting interval of 8 weeks in all the periods of the year 2007 compared with where the frequent interval of 4 weeks was used (Table 7). Application of nitrogen fertilizer significantly increased plant height only at the early period of the year. Cutting every 8-week with 300 and $0 \mathrm{~kg} \mathrm{~N} \mathrm{ha}^{-1}$, gave the tallest plants in grass-legume-mixed swards at the first and last periods, respectively, while the tallest plant was produced in pure 
Onyeonagu, C. C. ${ }^{*}$ and Asiegbu, J. E.

Table 6: Effect of Sward type, cutting frequency and fertilizer $\mathbf{N}$ application on height of verano stylo plant $(\mathrm{cm})$ at two periods of 2006

\begin{tabular}{|c|c|c|c|c|}
\hline & \multicolumn{4}{|c|}{ Cutting frequency (weeks) } \\
\hline Sward type & Fertilizer $\mathrm{N}\left(\mathrm{kg} \mathrm{ha}^{-1}\right)$ & 4 & 8 & Mean \\
\hline \multicolumn{5}{|c|}{ August $12-$ October 7 (1st 8-weeks period) } \\
\hline \multirow[t]{2}{*}{ Verano stylo } & 0 & 22.1 & 42.7 & 32.4 \\
\hline & 300 & 24.6 & 47.2 & 35.9 \\
\hline & Mean & 23.4 & 45.0 & 34.2 \\
\hline \multirow[t]{3}{*}{ Verano stylo in mixture } & 0 & 17.7 & 30.1 & 23.9 \\
\hline & 300 & 19.3 & 35.0 & 27.2 \\
\hline & Mean & 18.5 & 32.6 & 25.6 \\
\hline Cutting Frequency mean & & 20.9 & 38.8 & 29.9 \\
\hline \multirow[t]{2}{*}{ Fertilizer Mean: } & $0 \mathrm{~kg} \mathrm{Nha}^{-1}=28.2$ & \multicolumn{2}{|c|}{$300 \mathrm{~kg} \mathrm{Nha}^{-1}=31.6$} & \\
\hline & & December 2 & veeks period) & \\
\hline \multirow[t]{2}{*}{ Verano stylo } & 0 & 16.5 & 22.0 & 19.3 \\
\hline & 300 & 18.7 & 20.2 & 19.4 \\
\hline & Mean & 17.6 & 21.1 & 19.4 \\
\hline \multirow{3}{*}{ Verano stylo in mixture } & 0 & 17.8 & 21.1 & 19.5 \\
\hline & 300 & 25.6 & 17.0 & 21.3 \\
\hline & Mean & 21.7 & 19.1 & 20.4 \\
\hline \multirow{2}{*}{$\begin{array}{l}\text { Cutting Frequency Mean } \\
\text { Fertilizer Mean: }\end{array}$} & & 19.6 & 20.1 & 19.9 \\
\hline & $0 \mathrm{~kg} \mathrm{Nha}^{-1}=19.4$ & \multicolumn{2}{|c|}{$300 \mathrm{~kg} \mathrm{Nha}^{1}=20.4$} & \\
\hline & 1st period & $2^{\text {nd }}$ & \\
\hline \multirow{2}{*}{\multicolumn{2}{|c|}{ S.e.d. between 2 Sward Type means $(S)=$}} & & period & \\
\hline & & 1.35 & 1.88 & \\
\hline \multicolumn{2}{|c|}{ S.e.d. between 2 Cutting Frequency means $(C)=$} & 1.35 & 1.88 & \\
\hline \multicolumn{2}{|c|}{ S.e.d. between 2 Nitrogen means $(\mathrm{N})=$} & 1.35 & 1.88 & \\
\hline \multicolumn{2}{|l|}{ S.e.d. between $2 \mathrm{~S} X \mathrm{C}$ means $=$} & 1.91 & 2.65 & \\
\hline \multicolumn{2}{|l|}{ S.e.d. between $2 \mathrm{~S} X \mathrm{~N}$ means $=$} & 1.91 & 2.65 & \\
\hline \multicolumn{2}{|l|}{ S.e.d. between $2 \mathrm{CXN}$ means $=$} & 1.91 & 2.65 & \\
\hline \multicolumn{2}{|l|}{ S.e.d. between $2 \mathrm{~S} \times \mathrm{C} \times \mathrm{N}$ means $=$} & 2.69 & 3.75 & \\
\hline \multicolumn{2}{|l|}{ S.e.d. between $2 \mathrm{~S} X \mathrm{C} X \mathrm{~N}$ means $=$} & 2.69 & 3.75 & \\
\hline
\end{tabular}

legume swards during the second period, when fertilizer application was combined with the 8weekly interval of cuts. Plant height appeared to decrease with advancement in season.

The height of guinea grass plant increased significantly with increasing interval between cuts in 2006 and 2007 (Table 8). Sward type did not affect guinea grass height in both years. Fertilizer-N treatments did not influence height of grass plant in 2006 but increased it in 2007. Height of guinea grass plant was not affected by sward type $\mathrm{x}$ cutting interval $\mathrm{x}$ nitrogen application interaction in both years.

The 8-weekly interval of cut always increased the height of guinea grass plant in each of the two periods in the 2006 harvest season compared to the 4-weekly interval of cut (Table 9). Sward type had no significant effect on the plant height in any of the periods. Fertilizer application increased guinea grass height over where $\mathrm{N}$ was not applied only in the first period of the year. For similar cutting frequencies, average guinea grass height was always doubled during the first period compared with the second period of the harvest schedule.

During the second year, the height of the grass plant was significantly increased with increase in interval between cuts in all the harvest periods. Fertilizer application increased plant height in the first and second periods of the year (Table 10). Plant height did not differ significantly among the different sward types during the first and third periods of the year. Pure grass swards produced taller plants than grass-legume-mixed swards at the second period of the year. Tallest plants were obtained in grasslegume mixed swards when cutting was done at the longer interval of 8 weeks with fertilizer application during the first and third periods while cutting at 8 weeks interval gave the tallest plants when fertilizer was applied in pure grass swards at the second period. The height of grass plant appeared to increase with season. 
Sward Tvpe. Cutting Freauencv And Fertilizer-N Application On Pasture Establishment.

Table 7: Effect of Sward type, cutting frequency and fertilizer $\mathbf{N}$ application on height of verano stylo plant $(\mathrm{cm})$ at various periods of the year 2007

\begin{tabular}{|c|c|c|c|c|}
\hline & \multicolumn{4}{|c|}{ Cutting frequency (weeks) } \\
\hline Sward type & Fertilizer $\mathrm{N}\left(\mathrm{kg} \mathrm{ha}^{-1}\right)$ & 4 & 8 & Mean \\
\hline & \multicolumn{4}{|c|}{ May $29-$ July $24\left(1^{\text {st }} 8\right.$ weeks period $)$} \\
\hline \multirow[t]{3}{*}{ Verano stylo } & 0 & 25.5 & 35.8 & 30.6 \\
\hline & 300 & 28.5 & 44.7 & 36.6 \\
\hline & mean & 27.0 & 40.2 & 33.6 \\
\hline \multirow[t]{3}{*}{ Verano stylo in mixture } & 0 & 25.4 & 40.3 & 32.9 \\
\hline & 300 & 28.0 & 47.1 & 37.5 \\
\hline & mean & 26.7 & 43.7 & 35.2 \\
\hline Cutting Frequency mean & \multirow{2}{*}{\multicolumn{4}{|c|}{$\begin{array}{c}42.0 \\
300 \mathrm{~kg} \mathrm{Nha}^{-1}=37.1\end{array}$}} \\
\hline \multirow[t]{2}{*}{ Fertilizer mean: } & & & & \\
\hline & \multicolumn{4}{|c|}{ July $24-$ September 18 ( $2^{\text {nd }} 8$ weeks period $)$} \\
\hline \multirow[t]{3}{*}{ Verano stylo } & 0 & 21.4 & 30.8 & 26.1 \\
\hline & 300 & 21.8 & 33.5 & 27.7 \\
\hline & mean & 21.6 & 32.2 & 26.9 \\
\hline \multirow[t]{3}{*}{ Verano stylo in mixture } & 0 & 19.2 & 31.7 & 25.4 \\
\hline & 300 & 20.7 & 32.4 & 26.6 \\
\hline & mean & 19.9 & 32.1 & 26.0 \\
\hline Cutting Frequency mean & & 20.8 & 32.1 & 26.5 \\
\hline \multirow[t]{2}{*}{ Fertilizer mean: } & $0 \mathrm{~kg} \mathrm{Nha}^{-1}=25.8$ & & & \\
\hline & \multicolumn{4}{|c|}{ September $18-$ November $13\left(3^{\text {rd }} 8\right.$ weeks period $)$} \\
\hline \multirow[t]{3}{*}{ Verano stylo } & 0 & 22.4 & 27.9 & 25.1 \\
\hline & 300 & 22.2 & 27.9 & 25.1 \\
\hline & mean & 22.3 & 27.9 & 25.1 \\
\hline \multirow[t]{3}{*}{ Verano stylo in mixture } & 0 & 23.1 & 32.1 & 27.6 \\
\hline & 300 & 26.3 & 30.1 & 28.2 \\
\hline & mean & 24.7 & 31.1 & 27.9 \\
\hline Cutting Frequency mean & & 23.5 & 29.5 & 26.5 \\
\hline \multirow[t]{2}{*}{ Fertilizer mean: } & $0 \mathrm{~kg} \mathrm{Nha}^{-1}=26.4$ & \multicolumn{3}{|c|}{$300 \mathrm{~kg} \mathrm{Nha}^{-1}=26.6$} \\
\hline & & $1^{\text {st }}$ period & 2nd period & 3rd period \\
\hline d. between 2 Sward Type & & 1.22 & 0.89 & 1.13 \\
\hline d. between 2 Cutting Freq & $\operatorname{ans}(\mathrm{C})=$ & 1.22 & 0.89 & 1.13 \\
\hline d. between 2 Nitrogen me & & 1.22 & 0.89 & 1.13 \\
\hline d. between $2 \mathrm{~S}$ X C mean & & 1.72 & 1.26 & 1.60 \\
\hline d. between $2 \mathrm{~S} X \mathrm{~N}$ mean & & 1.72 & 1.26 & 1.60 \\
\hline d. between $2 \mathrm{C} \mathrm{X} \mathrm{N} \mathrm{mean}$ & & 1.72 & 1.26 & 1.60 \\
\hline d. between $2 \mathrm{~S}$ X C X N n & & 2.43 & 1.78 & 2.27 \\
\hline
\end{tabular}

Table 8: Effects of sward type, cutting frequency and fertilizer-N application on height (cm) of guinea grass (Panicum maximum) in 2006 and 2007

\begin{tabular}{|c|c|c|c|c|c|}
\hline & & \multicolumn{4}{|c|}{ Cutting frequency (weeks) } \\
\hline Sward type & Fertilizer-N $\left(\mathrm{kg} \mathrm{ha}^{-1}\right)$ & 4 & 8 & 12 & Mean \\
\hline \multirow{3}{*}{ Guinea grass } & & \multicolumn{3}{|c|}{2006} & \\
\hline & 0 & 50.5 & 105.9 & 200.0 & 118.8 \\
\hline & 300 & 60.2 & 106.1 & 198.8 & 121.7 \\
\hline \multirow{3}{*}{ Guinea grass in mixture } & Mean & 55.4 & 106.0 & 199.4 & 120.2 \\
\hline & 0 & 49.8 & 107.1 & 200.2 & 119.0 \\
\hline & 300 & 56.4 & 121.2 & 203.9 & 127.1 \\
\hline \multirow{4}{*}{$\begin{array}{l}\text { Cutting Frequency mean } \\
\text { Fertilizer Mean }\end{array}$} & \multirow{4}{*}{$0 \mathrm{~kg} \mathrm{Nha}{ }^{-1}=118.9$} & 53.1 & 114.1 & 202.0 & 123.1 \\
\hline & & 54.2 & 110.1 & 200.7 & 121.7 \\
\hline & & \multicolumn{3}{|c|}{$300 \mathrm{~kg}$} & \\
\hline & & \multirow{2}{*}{\multicolumn{3}{|c|}{$\begin{array}{r}\text { Nha }^{-1}=124.4 \\
2007\end{array}$}} & \\
\hline & & & & & \\
\hline \multirow[t]{2}{*}{ Guinea grass } & 0 & 38.7 & 84.8 & 136.6 & 86.7 \\
\hline & 00 & 45.6 & 93.5 & 141.6 & 93.6 \\
\hline \multirow{4}{*}{ Guinea grass in mixture } & Mean & 42.1 & 89.2 & 139.1 & 90.1 \\
\hline & 0 & 37.0 & 83.3 & 142.2 & 87.5 \\
\hline & 300 & 51.8 & 97.0 & 140.4 & 96.4 \\
\hline & Mean & 44.4 & 90.2 & 141.3 & 92.0 \\
\hline Cutting Frequency mean & \multirow[b]{2}{*}{$0 \mathrm{~kg} \mathrm{Nha}{ }^{-1}=87.1$} & 43.3 & 89.7 & 140.2 & 91.0 \\
\hline Fertilizer Mean & & \multicolumn{3}{|c|}{$300 \mathrm{~kg} \mathrm{Nha}^{-1}=95.0$} & \\
\hline & 2006 & \multicolumn{2}{|l|}{2007} & \\
\hline & S.e.d. between 2 Sward Type means $(S)=$ & 3.50 & 2.98 & & \\
\hline \multirow{2}{*}{\multicolumn{2}{|c|}{$\begin{array}{l}\text {.e.d. between } 2 \text { Cutting Frequency means }(C)= \\
\text {.e.d. between } 2 \text { Nitrogen means }(N)=\end{array}$}} & 4.29 & 3.64 & & \\
\hline & S.e.d. between 2 Nitrogen means $(N)=$ & 3.50 & 2.98 & & \\
\hline \multicolumn{2}{|c|}{ s.e.d. between $2 \mathrm{~S} \times \mathrm{C}$ means $=$} & 6.06 & 5.15 & & \\
\hline \multicolumn{2}{|c|}{ S.e.d. between $2 \mathrm{~S} X \mathrm{~N}$ means $=$} & 4.95 & 4.21 & & \\
\hline & 6.06 & 5.15 & & \\
\hline \multicolumn{2}{|c|}{$\begin{array}{l}\text { e.d. between } 2 \text { C X N means = } \\
\text { e.d. between } 2 \mathrm{~S} \text { X C X N means = }\end{array}$} & 8.57 & 7.29 & & \\
\hline
\end{tabular}


Onyeonagu, C. C. ${ }^{*}$ and Asiegbu, J. E.

Table 9: Effect of Sward type, cutting frequency and fertilizer $N$ application on height of guinea grass plant $(\mathrm{cm})$ at two periods of 2006

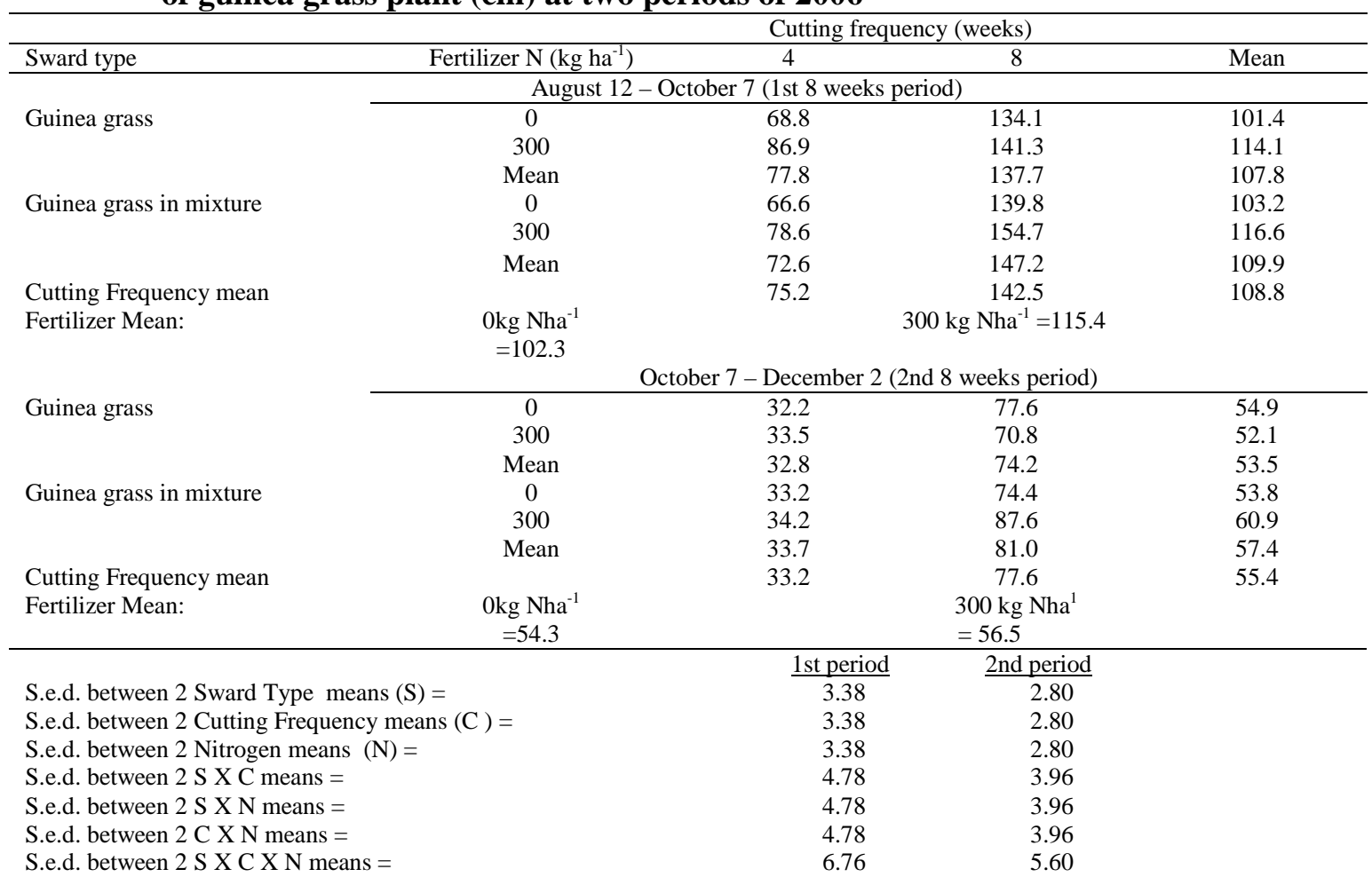

In the 2006 harvest year, infrequent cutting interval of 12 weeks produced significantly the highest number of leaves per verano stylo plant compared with the other intervals (Table 11). The number of leaves per plants increased significantly with increase in intervals between cuts up to the 8-weekly interval in 2007. Number of leaves per plant remained the same for the 4 weeks compared with 8-week intervals of cuts in 2006. Four and 12 weekly intervals of cut had similar effects on the number of leaves per plants in 2007. Fertilizer-N application had no effect on the number of leaves per plant in both years. Plots with verano stylo swards produced significantly greater number of leaves than where verano stylo was in mixture with guinea grass in 2006. In 2007, verano stylo grown in mixture with guinea grass had significantly greater number of leaves per plant compared with pure verano stylo swards. Harvesting every 12 weeks gave significantly the highest number of leaves per plant under pure legume swards in 2006. The number of leaves per legume plant was not affected by sward type $\mathrm{x}$ cutting interval $\mathrm{x}$ nitrogen application interaction in both years.

The legume plant produced greater number of leaves per plant when cutting was done every 8 weeks than 4 weeks at the first period of the year 2006 (Table 12). The number of leaves per plant was not affected at any cutting interval during the second period. Fertilizer-N application did not influence the number of leaves per plant at any of the periods. Pure legume swards consistently produced greater number of leaves per plant at both periods when compared with where the legume plant was grown in mixture with grass. The number of leave per plant appeared to increase with season.

The infrequent cutting interval of 8weeks consistently produced significantly greater number of leaves in all the periods in 2007 than the 4 weeks (Table 13). Fertilizer-N application had no effect on the number of leaves per plant in any of the periods. Greater number of leaves per plant was produced in legume plants grown in mixture with grass compared to those grown alone during the first and second periods. Type of sward treatment did not influence the number of leaves per plant at the third period. The number of leaves appeared to decrease with increase in season. 
Sward Tvpe. Cutting Freauencv And Fertilizer-N Application On Pasture Establishment.

Table 10: Effect of Sward type, cutting frequency and fertilizer $\mathrm{N}$ application on height of grass plant $(\mathrm{cm})$ at various periods of the year 2007

\begin{tabular}{|c|c|c|c|c|}
\hline & \multicolumn{4}{|c|}{ Cutting frequency (weeks) } \\
\hline Sward type & $\begin{array}{c}\text { Fertilizer N (kg } \\
\left.\mathrm{ha}^{-1}\right)\end{array}$ & 4 & 8 & Mean \\
\hline \multirow{4}{*}{ Guinea grass } & \multicolumn{4}{|c|}{ May $29-$ July $24\left(1^{\text {st }} 8\right.$ weeks period $)$} \\
\hline & 0 & 29.0 & 74.9 & 51.9 \\
\hline & 300 & 42.7 & 89.5 & 66.1 \\
\hline & mean & 35.9 & 82.2 & 59.0 \\
\hline \multirow[t]{3}{*}{ Guinea grass in mixture } & 0 & 33.0 & 80.0 & 56.5 \\
\hline & 300 & 53.9 & 94.5 & 74.2 \\
\hline & mean & 43.4 & 87.2 & 65.3 \\
\hline \multirow{3}{*}{ Fertilizer mean: } & & 39.7 & 84.7 & 62.2 \\
\hline & $\begin{array}{l}0 \mathrm{~kg} \mathrm{Nha}{ }^{-1} \\
=54.2\end{array}$ & & $\begin{array}{r}300 \mathrm{~kg} \mathrm{Nh} \\
=70.2\end{array}$ & \\
\hline & & July 24 & $8\left(2^{\text {nd }} 8\right.$ weeks & \\
\hline \multirow[t]{3}{*}{ Guinea grass } & 0 & 29.0 & 72.4 & 50.7 \\
\hline & 300 & 41.3 & 87.0 & 64.2 \\
\hline & mean & 35.1 & 79.7 & 57.4 \\
\hline \multirow{3}{*}{ Guinea grass in mixture } & 0 & 31.2 & 62.0 & 46.6 \\
\hline & 300 & 37.5 & 86.1 & 61.8 \\
\hline & mean & 34.4 & 74.0 & 54.2 \\
\hline Cutting Frequency & & 34.8 & 76.9 & 55.8 \\
\hline \multirow[t]{2}{*}{ Fertilizer mean: } & $\begin{array}{l}\text { 0kg Nha }{ }^{-1} \\
=48.6\end{array}$ & & $\begin{array}{r}300 \mathrm{~kg} \mathrm{Nh} \\
=63.0\end{array}$ & \\
\hline & & September & er $13\left(3^{\text {rd }} 8\right.$ we & \\
\hline \multirow[t]{3}{*}{ Guinea grass } & 0 & 54.6 & 107.2 & 80.9 \\
\hline & 300 & 52.8 & 104.0 & 78.4 \\
\hline & mean & 53.7 & 105.6 & 79.6 \\
\hline \multirow[t]{3}{*}{ Guinea grass in mixture } & 0 & 46.8 & 107.9 & 77.3 \\
\hline & 300 & 63.9 & 110.4 & 87.1 \\
\hline & mean & 55.4 & 109.1 & 82.2 \\
\hline Cutting Frequency mean & & 54.5 & 107.4 & 80.9 \\
\hline \multirow[t]{2}{*}{ Fertilizer mean: } & $\begin{array}{l}\text { Okg Nha }{ }^{-1} \\
=79.1\end{array}$ & & $\begin{array}{r}300 \mathrm{~kg} \mathrm{Nh} \\
=82.8\end{array}$ & \\
\hline & & $1^{\text {st }}$ period & 2nd period & 3rd period \\
\hline \multicolumn{2}{|c|}{ d. between 2 Sward Type means $(S)=$} & 5.40 & 2.87 & 7.15 \\
\hline \multicolumn{2}{|c|}{ d. between 2 Cutting Frequency means $(C)=$} & 5.40 & 2.87 & 7.15 \\
\hline \multicolumn{2}{|c|}{ d. between 2 Nitrogen means $(\mathrm{N})=$} & 5.40 & 2.87 & 7.15 \\
\hline \multicolumn{2}{|c|}{ d. between $2 \mathrm{~S} \times \mathrm{C}$ means $=$} & 7.64 & 4.06 & 10.11 \\
\hline \multicolumn{2}{|c|}{ d. between $2 \mathrm{~S} X \mathrm{~N}$ means $=$} & 7.64 & 4.06 & 10.11 \\
\hline \multicolumn{2}{|c|}{ d. between $2 \mathrm{CXN}$ means $=$} & 7.64 & 4.06 & 10.11 \\
\hline \multicolumn{2}{|c|}{ d. between $2 \mathrm{~S} X \mathrm{C} X \mathrm{~N}$ means $=$} & 10.80 & 5.76 & 14.29 \\
\hline
\end{tabular}

The infrequent cutting interval of 12 weeks produced significantly the highest number of branches per verano stylo plant compared with the other intervals of cuts during the establishment year (Table 14). Four and 8-weeks intervals of cut did not differ in their effects on the number of branches per plant. Eight weekly interval of cut produced greater number of branches than the 4weekly interval but had similar effect with the 12 week interval of cuts in 2007. Fertilizer-N application had no effect on the number of branches per plant in both years. Greater number of branches per plant was produced in pure verano stylo swards in 2006 compared with where verano stylo was grown in mixture with guinea grass. In 2007, verano stylo plants grown in mixture with guinea grass produced significantly greater number of branches compared with pure verano stylo swards. Cutting every 12 weeks gave significantly the highest number of branches per plant when verano stylo plants were grown alone in 2006. Cutting interval, sward type and fertilizer application did not interact significantly to produce differential number of branches per plant in 2007. 
Onyeonagu, C. C. ${ }^{*}$ and Asiegbu, J. E.

Table 11: Effects of sward type, cutting frequency and fertilizer-N application on number of leaves per Verano stylo plant in 2006 and 2007

\begin{tabular}{|c|c|c|c|c|c|}
\hline \multirow[b]{2}{*}{ Sward type } & \multirow[b]{2}{*}{ Fertilizer-N $\left(\mathrm{kg} \mathrm{ha}^{-1}\right)$} & \multicolumn{4}{|c|}{ Cutting frequency (weeks) } \\
\hline & & 4 & 8 & 12 & Mean \\
\hline \multirow{4}{*}{ Verano stylo } & & & 2006 & & \\
\hline & 0 & 127.6 & 108.7 & 221.2 & 152.5 \\
\hline & 300 & 114.3 & 150.0 & 330.2 & 198.2 \\
\hline & Mean & 121.0 & 129.4 & 275.7 & 175.3 \\
\hline \multirow[t]{3}{*}{ Verano stylo in mixture } & 0 & 61.3 & 54.1 & 115.5 & 77.0 \\
\hline & 300 & 54.0 & 67.4 & 97.3 & 72.9 \\
\hline & Mean & 57.7 & 60.8 & 106.4 & 74.9 \\
\hline Cutting Frequency Mean & & 89.3 & 95.1 & 191.1 & 125.1 \\
\hline Fertilizer Mean & $0 \mathrm{~kg} \mathrm{Nha}^{-1}=114.7$ & & $\begin{array}{l}300 \mathrm{~kg} \mathrm{Nha}^{-1} \\
=135.5\end{array}$ & & \\
\hline & & & 2007 & & \\
\hline \multirow[t]{3}{*}{ Verano stylo } & 0 & 70.8 & 92.3 & 105.6 & 89.6 \\
\hline & 300 & 87.8 & 112.9 & 74.7 & 91.8 \\
\hline & Mean & 79.3 & 102.6 & 90.1 & 90.7 \\
\hline \multirow[t]{3}{*}{ Verano stylo in mixture } & 0 & 87.8 & 155.1 & 123.9 & 122.2 \\
\hline & 300 & 110.5 & 147.7 & 142.7 & 133.6 \\
\hline & Mean & 99.2 & 151.4 & 133.3 & 127.9 \\
\hline Cutting Frequency Mean & & 89.2 & 127.0 & 111.7 & 109.3 \\
\hline Fertilizer Mean & $0 \mathrm{~kg} \mathrm{Nha}^{-1}=105.9$ & & $\begin{array}{l}300 \mathrm{~kg} \mathrm{Nha}^{-1} \\
=112.7\end{array}$ & & \\
\hline
\end{tabular}

S.e.d. between 2 Sward Type means $(\mathrm{S})=$

$\begin{array}{ll}\frac{2006}{16.08} & \frac{2007}{7.13} \\ 19.70 & 8.73 \\ 16.08 & 7.13 \\ 27.86 & 12.35 \\ 22.74 & 10.08 \\ 27.86 & 12.35 \\ 39.39 & 17.46\end{array}$

S.e.d. between 2 Cutting Frequency means $(\mathrm{C})=$

S.e.d. between 2 Nitrogen means $(\mathrm{N})=$

S.e.d. between $2 \mathrm{~S} X \mathrm{C}$ means =

S.e.d. between $2 \mathrm{~S} X \mathrm{~N}$ means $=$

S.e.d. between $2 \mathrm{C} \mathrm{X} \mathrm{N}$ means $=$

S.e.d. between $2 \mathrm{~S}$ X C X N means =

39.39

17.46

Table 12: Effect of Sward type, cutting frequency and fertilizer $\mathbf{N}$ application on number of leaves per Verano stylo plant at various periods of the year 2006

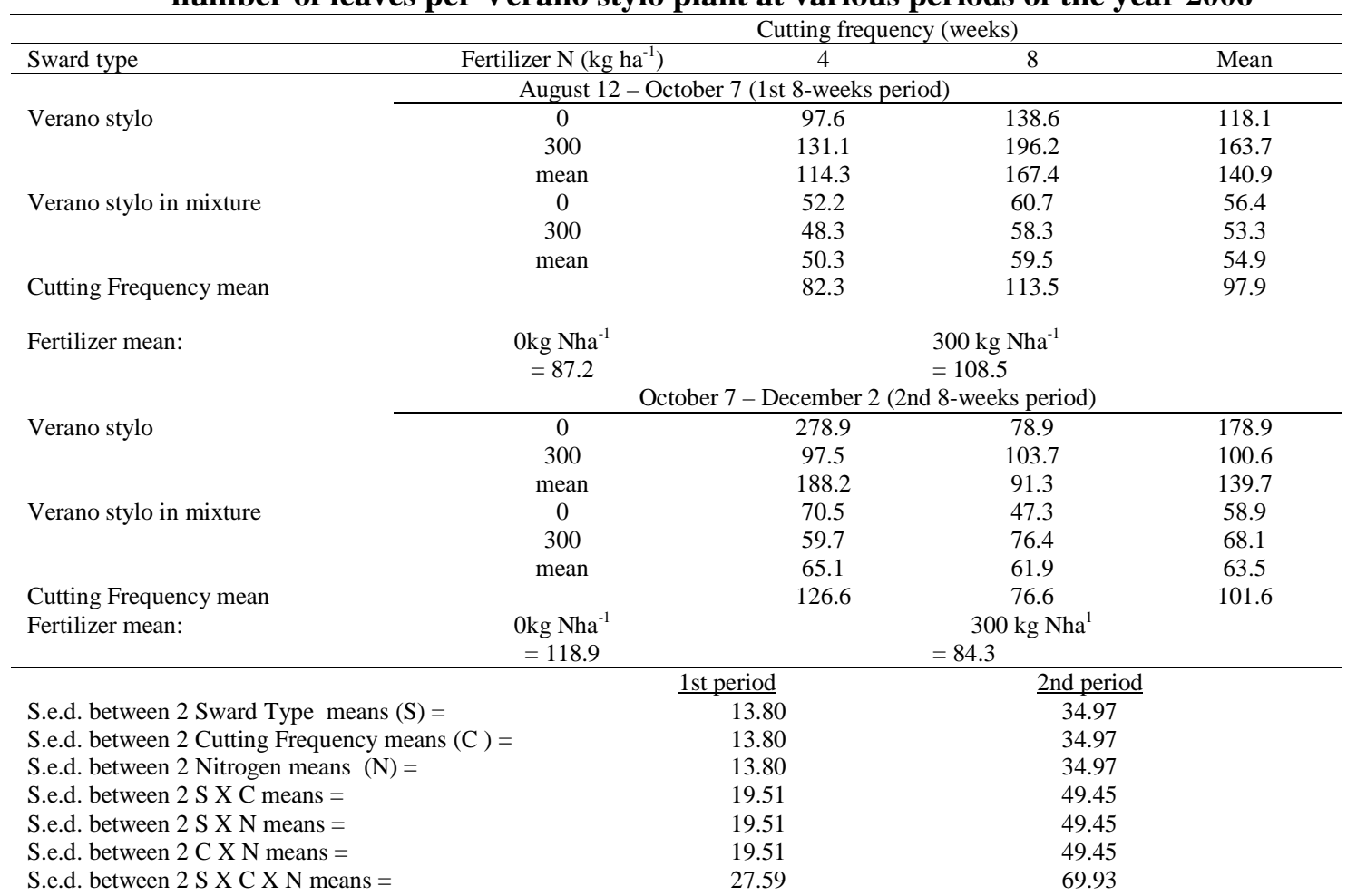


Sward Tvpe. Cutting Freauencv And Fertilizer-N Application On Pasture Establishment.

Table 13: Effect of Sward type, cutting frequency and fertilizer $\mathbf{N}$ application on number of leaves per Verano stylo plant at various periods of the year 2007

\begin{tabular}{|c|c|c|c|c|}
\hline & \multicolumn{4}{|c|}{ Cutting frequency (weeks) } \\
\hline Sward type & Fertilizer $\mathrm{N}\left(\mathrm{kg} \mathrm{ha}^{-1}\right)$ & 4 & 8 & Mean \\
\hline & \multicolumn{4}{|c|}{ May $29-$ July $24\left(1^{\text {st }} 8\right.$ weeks period $)$} \\
\hline \multirow[t]{3}{*}{ Verano stylo } & 0 & 87.5 & 66.6 & 77.0 \\
\hline & 300 & 96.1 & 110.7 & 103.4 \\
\hline & mean & 91.8 & 88.6 & 90.2 \\
\hline \multirow[t]{3}{*}{ Verano stylo in mixture } & 0 & 103.3 & 179.1 & 141.2 \\
\hline & 300 & 102.9 & 170.0 & 136.5 \\
\hline & mean & 103.1 & 174.6 & 138.8 \\
\hline Cutting Frequency mean & & 97.5 & 131.6 & 114.5 \\
\hline \multirow[t]{2}{*}{ Fertilizer mean: } & $0 \mathrm{~kg} \mathrm{Nha}{ }^{-1}=109.1$ & \multirow{2}{*}{\multicolumn{3}{|c|}{$\begin{array}{r}300 \mathrm{~kg} \mathrm{Nha}^{-1}=119.9 \\
\text { July } 24-\text { September } 18\left(2^{\text {nd }} 8 \text { weeks period }\right)\end{array}$}} \\
\hline & & & & \\
\hline \multirow[t]{3}{*}{ Verano stylo } & 0 & 64.8 & 134.7 & 99.8 \\
\hline & 300 & 92.4 & 96.3 & 94.3 \\
\hline & mean & 78.6 & 115.5 & 97.0 \\
\hline \multirow[t]{3}{*}{ Verano stylo in mixture } & 0 & 80.2 & 161.8 & 121.0 \\
\hline & 300 & 138.9 & 146.9 & 142.9 \\
\hline & mean & 109.5 & 154.3 & 131.9 \\
\hline Cutting Frequency mean & & 94.1 & 134.9 & 114.5 \\
\hline \multirow[t]{2}{*}{ Fertilizer mean: } & $0 \mathrm{~kg} \mathrm{Nha}^{-1}=110.4$ & & $300 \mathrm{~kg} \mathrm{Nha}^{-1}=1$ & \\
\hline & & \multicolumn{3}{|c|}{ September 18 - November $13\left(3^{\text {rd }} 8\right.$ weeks period $)$} \\
\hline \multirow{3}{*}{ Verano stylo } & 0 & 67.9 & 75.8 & 71.9 \\
\hline & 300 & 74.9 & 132.3 & 103.6 \\
\hline & mean & 71.4 & 104.1 & 87.8 \\
\hline \multirow[t]{3}{*}{ Verano stylo in mixture } & 0 & 79.9 & 124.3 & 102.1 \\
\hline & 300 & 89.7 & 126.2 & 108.0 \\
\hline & mean & 84.8 & 125.3 & 105.0 \\
\hline Cutting Frequency mean & & 78.1 & 114.7 & 96.4 \\
\hline \multirow[t]{2}{*}{ Fertilizer mean: } & $0 \mathrm{~kg} \mathrm{Nha}^{-1}=87.0$ & \multicolumn{3}{|c|}{$300 \mathrm{~kg} \mathrm{Nha}^{-1}=105.8$} \\
\hline & & $1^{\text {st }}$ period & 2nd period & 3rd period \\
\hline d. between 2 Sward Type & $\operatorname{ans}(S)=$ & 12.68 & 13.88 & 13.31 \\
\hline d. between 2 Cutting inte & means $(\mathrm{C})=$ & 12.68 & 13.88 & 13.31 \\
\hline d. between 2 Nitrogen me & $(\mathrm{N})=$ & 12.68 & 13.88 & 13.31 \\
\hline d. between $2 \mathrm{~S} X \mathrm{C}$ mean & & 17.94 & 19.63 & 18.82 \\
\hline d. between $2 \mathrm{~S} X \mathrm{~N}$ mean & & 17.94 & 19.63 & 18.82 \\
\hline d. between $2 \mathrm{CX} \mathrm{N}$ mean & & 17.94 & 19.63 & 18.82 \\
\hline d. between $2 \mathrm{~S}$ X C X N & & 25.37 & 27.76 & 26.61 \\
\hline
\end{tabular}

During the first period of the year 2006, the infrequent cutting interval of 8 weeks significantly produced greater number of branches per legume plant compared with the 4 weeks (Table 15). Cutting interval did not influence the number of branches per plant at the second period. Fertilizer-N application showed no effect on the number of branches per plant at both periods. Greater number of branches was obtained in pure legume swards compared with where legume was in mixture with grass at both periods. The number of branches per plant appeared to increase with season.
Cutting interval treatment had a significant effect on the number of branches per legume plant only at the third period of 2007; where the 8 weeks interval produced greater number of branches than the 4 weeks (Table 16). Fertilizer-N application did not influence the number of branches per plant at any period. The legume plants grown in mixture with grass produced significantly greater number of plant branches than where legume was grown alone during the first two periods. Sward type had no effect on the number of branches at the third period of the year. 
Table 14: Effects of sward type, cutting frequency and fertilizer-N application on number of the branches per Verano stylo plant in 2006 and 2007

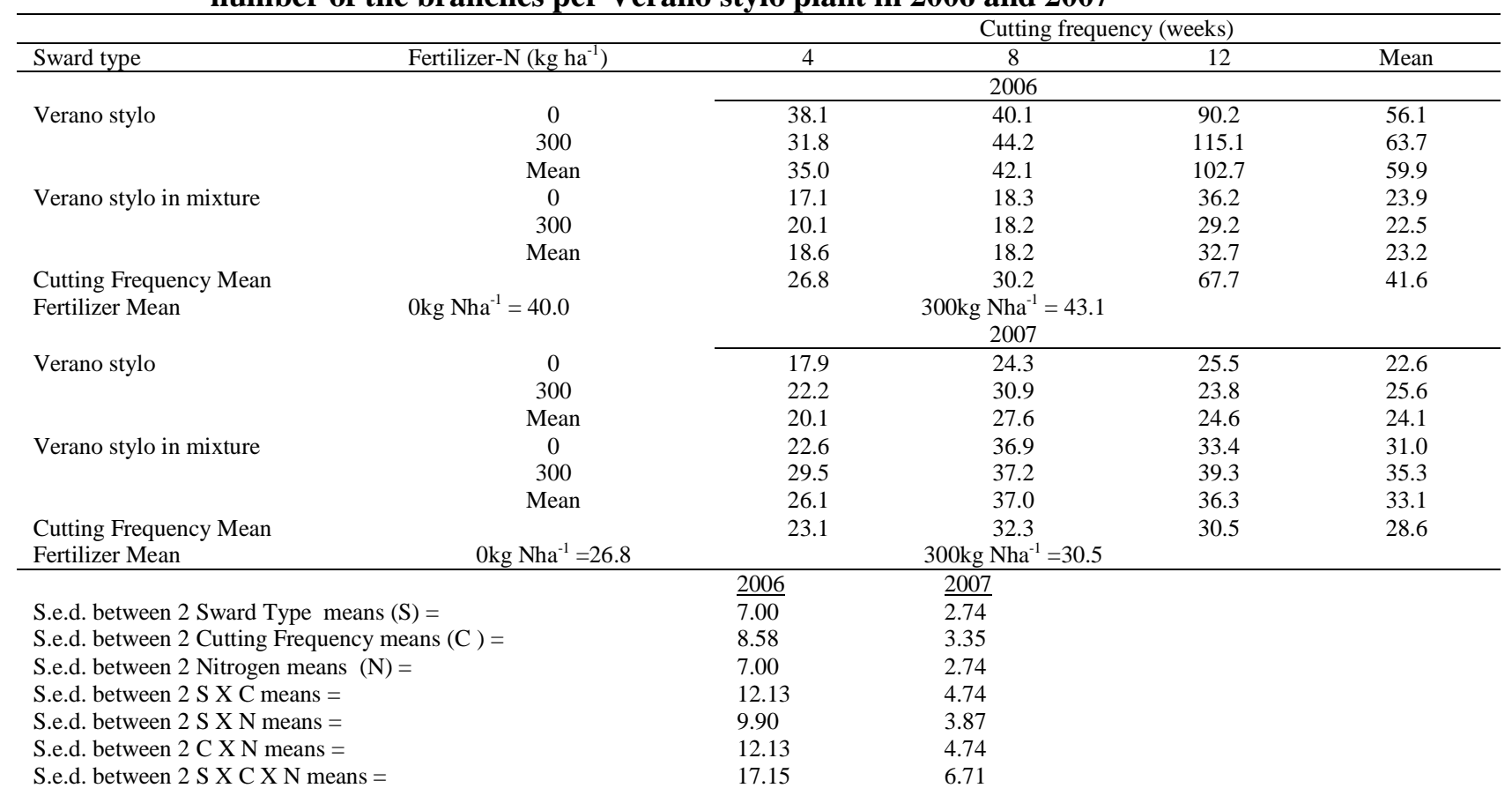

Table 15: Effect of Sward type, cutting frequency and fertilizer $N$ application on the number of branches per Verano stylo plant at various periods of the year 2006

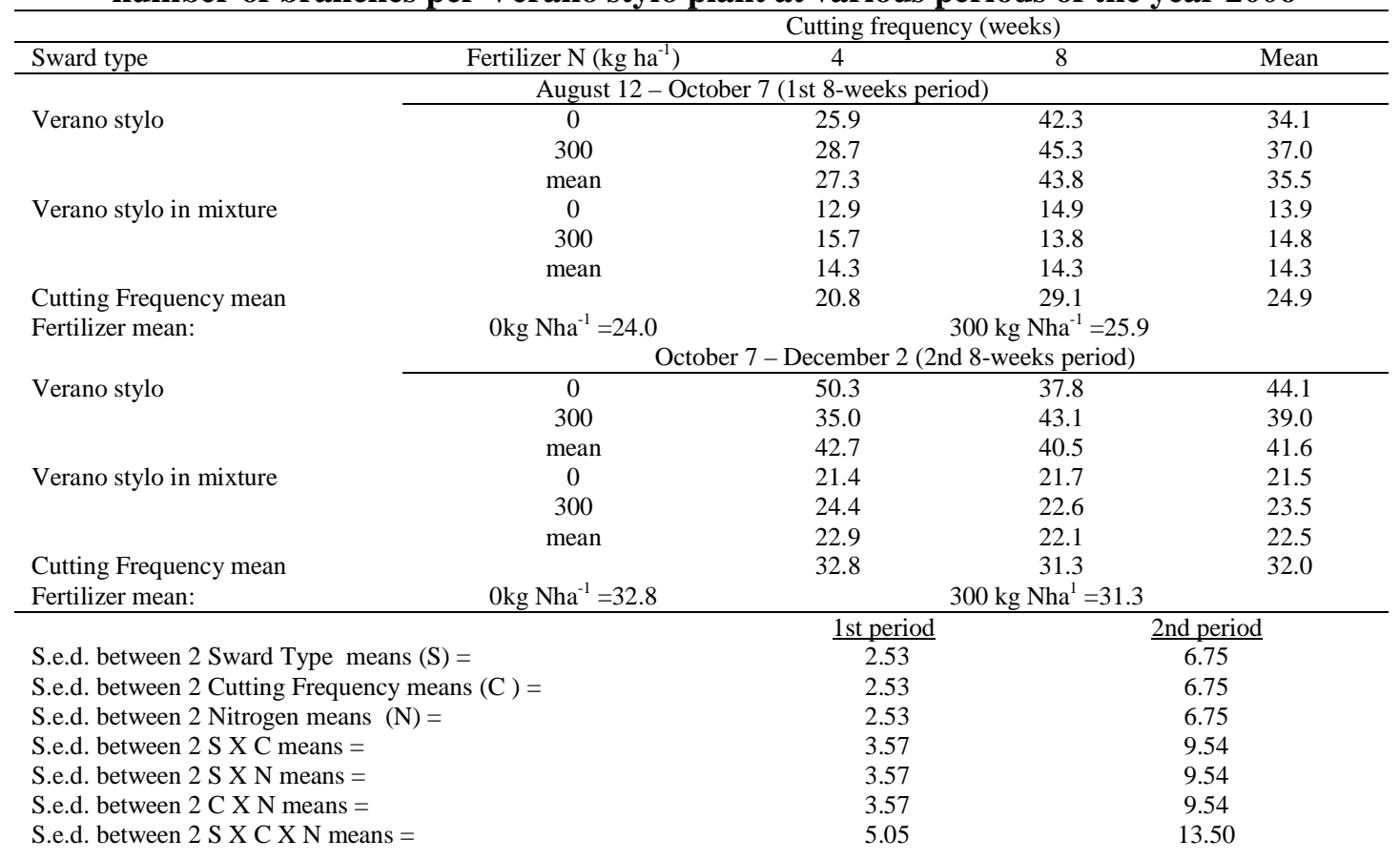


Sward Tvpe. Cutting Freauencv And Fertilizer-N Application On Pasture Establishment.

Table 16: Effect of Sward type, cutting frequency and fertilizer $\mathbf{N}$ application on the number of branches per Verano stylo plant at various periods of the year 2007

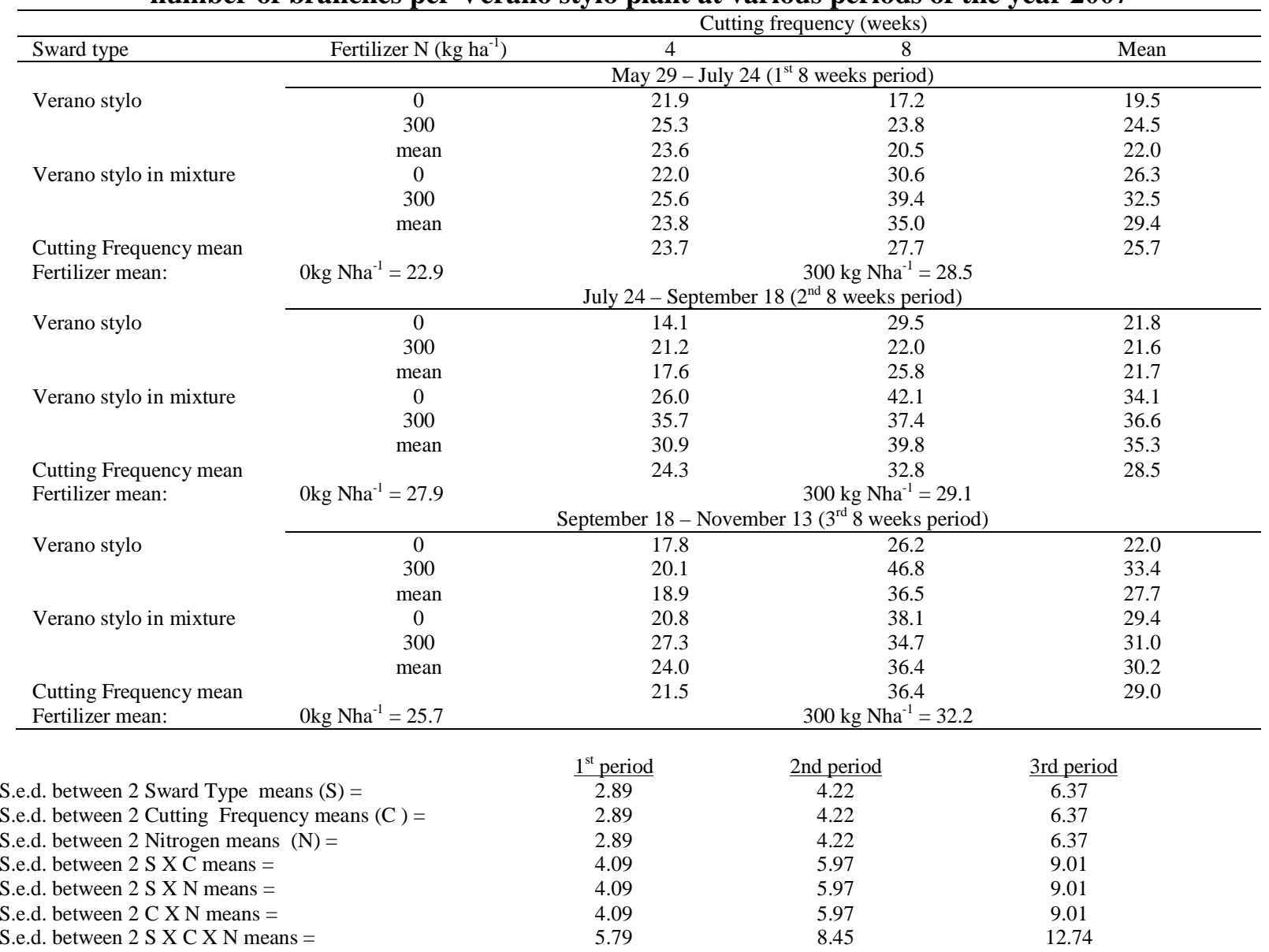

\section{DISCUSSION}

The significant reductions in the height, number of branches and number of leaves per legume plant occasionally observed in grasslegume mixed swards in the present work had earlier been shown as some morphogenetic changes; which are presumably mechanisms for individual plants to adapt to changes in light resource availability (Ballare et al., 1995). Changes in sward structure resulting from fragmentation and loss of individuals or species had been shown to alter light environment and further influenced competitive interactions among plants (Ballare et al., 1995).

The significant increase in heights of grass and legume species with increase in interval between cuts and with nitrogen application has also being reported earlier by Wilman and Asiegbu (1982). Working with perennial ryegrass (Lolium perenne) in a perennial ryegrass-white clover swards, these authors obtained the highest plant height with 8 12 weeks interval of cuts and the lowest with 3weekly interval. They also reported that plant height increased with incremental application of fertilizer $\mathrm{N}$, indicating that higher plant height with increasing application of $\mathrm{N}$ could partly be explained with the propensity for greater leaf area with increasing $\mathrm{N}$ rates.

Nitrogen application has been shown to stimulate grass growth and conversely reduce legume growth in a mixed sward (Brunet et al., 1990; Aydin and Uzun, 2005). To encourage stylo in mixture with guinea grass and maintain a balance in the growth and proportions of grass and legume in mixture, one needs to take into account, the adverse effect of defoliation as well as of the potential benefit of defoliation in terms of reduced competition from grass; when grass is not competing strongly, the stylo may benefit from a period of uninterrupted growth, whereas, when the grass is competing strongly and over- 
growing the stylo, defoliation may provide some net benefit to the stylo. Wilman and Asiegbu (1982) showed that reduction in grass tiller density of perennial ryegrass (Lolium perenne) in a perennial ryegrass-white clover swards; as a result of increasing the interval between harvests, favoured the legume whereas the greater difference in height between the grass and the legume with the longer intervals acted against the legume. This could account for the reduction in height, number of leaves per plant and number of branches per legume plant in mixture with grass as observed in the present work.

The low dry matter yields of herbage obtained at 8 weeks after planting apparently resulted from the poor nutrient status of the soil. The soil of the experimental site of the present study was low in nitrogen, potassium, magnesium, and base saturation and was acidic in reaction. The observed nutrient deficiencies of the site could partly account for the low productivity.

The general reduction in plant growth obtained during the dry season had been recognized for tropical pastures (Onyeonagu and Asiegbu, 2005). Increases in plant height, number of leaves per plant and number of branches per plant obtained in the present study followed the rainfall patterns in 2006 and 2007 seasons. Whether for 4 or 8 weeks interval of cuts, the October-December or SeptemberNovember periods generally had the least values of the above parameters compared with the MayOctober periods. This could be partly attributed to reduced moisture and nutrient availability and uptake at the dry periods of 2006 and 2007.

\section{REFERENCES}

Aydin, I. and Uzun, F. (2005): Nitrogen and phosphorus fertilization of rangelands affects yield, forage quality and the botanical composition. European Journal of Agronomy, 23(1): 8-14.

Bamikole, M.A.; Akinsoyinu, A.O.; Ezenwa, I.; Babayemi, O.J.; Akinlade, J. and Adewumi, K. (2004). Effect of six-weekly harvests on the yield, chemical composition and dry matter degradability of Panicum maximum and Stylosanthes hamata in Nigeria. Grass and Forage Science 59, (4) 357 - 363.

Ballare, C.L., Scopel, R.A., and Sanchez, R.A. (1995): Plant morphogenesis in canopies, crop growth and yield. HortScience 30:1172 - 1181.
Brunet, E.; Avila, A.; Rios, C. and Almaguer, J. (1990). Response of four irrigated pasture grasses to $\mathrm{N}$-applications. Suelos Y. Agroquimica (Cuba) 13 (1): $43-52$.

Casler, M. D. (1988). Performance of orchardgrass, smooth bromegrass and ryegrass in binary mixtures with alfalfa. Agron. J. 80: 509-514.

Casler, M. D. and Walgenbach (1990). Ground cover potential of forage grass cultivars mixed with alfalfa at divergent locations. Crop Sci. 30: 825 - 831.

Guay, J. F. (2001). Compatibility, yield, and quality of matua prairie grass, (Bromus willdenowii kunth), with legumes. M.Sc. Thesis submitted to the Faculty of Virginia Polytechnic Institute and State University $85 p$.

Haggar, R.J. (1971): The production and management of stylosanthes gracilis at Shika, Nigeria. I. in sown Pastures. Journal of British Grassland Society 32, 195-240

Humphreys, L. R. (1980). Tropical pasture and fodder crops. 2nd Edition. Longman Group Ltd. London 135pp.

Jung, G.A., Shaffer, J.A. and Everhart, J.R. (1994). Fall Management effect on Matua prairie grass production and sward characteristics. Agron. J. 86: $1032-1039$.

Omaliko, C. P. E. (1980). Influence of initial cutting date and cutting frequency on yield and quality of star, elephant and guinea grass. Grasslands and Forage Science, 35: 139 - 145.

Onyeonagu, C.C. and Asiegbu, J.E. (2005). Herbage leaf to stem ratio and yield distribution over time as influenced by cutting frequency and $\mathrm{N}$-fertilizer application in an old run-down Panicum maximum pasture. Journal of Agriculture, Food, Environment and Extension 4 (1): 74 - 77.

Rhodes, I., and W. R. Stern (1978): In 'Plant relations in pastures'. (J. R. Wilson, ed) CSIRO, East Melbourne, Australia. pp. 175-189.

Steel, G. D. and Torrie, J. A. (1980). Principles and procedure of statistics: A biometrical approach, 2nd edition, McGraw - Hill 
Book Company, Inc. New York 6331, pp. xxxi.

Turner, K. E.; Belesky, D. P.; Fedders, J. M. and Solomon, M. B. (1998). Autumn grazedorchardgrass-white clover pasture: Nutritive value of herbage and lamb performance. Prod. Agric. 11: 85 - 91.

Wilman, D. and Asiegbu, J. E. (1982). The effect of clover variety, cutting interval and nitrogen application on herbage yields, proportions and heights in perennial ryegrass. White clover swards. Grasslands and Forage science 37, 1 13.

Wong, C.C. and Wilson, J.R. (2005). Effects of shading on the growth and nitrogen Content of green panic and Siratro in pure and mixed swards defoliated at two frequencies. Australian Journal of Agricultural Research 31 (2): 269- 285. 